International Journal of Life Sciences
Available online at www.sciencescholar.us
Vol. 4 No. 3, December 2020, pages: 72-79
e-ISSN: 2550-6986, p-ISSN: 2550-6994
https://doi.org/10.29332/ijls.v4n3.580

\title{
The Relationship of Agro-climatic Characteristics in Flowering Phenology of Siam Citr Plants (Citrus nobillias Var microcarpa L)
}

\begin{tabular}{l} 
Ni Putu Anom Sulistiawatia, Nengah Suaria ${ }^{\text {b }}$, Ni Komang Alit Astiaric \\
Manuscript submitted: 27 October 2020, Manuscript revised: 18 November 2020, Accepted for publication: 09 December 2020 \\
\hline Corresponding Author a \\
$\begin{array}{l}\text { Abstract } \\
\text { The productivity of citrus plants in Indonesia is still low. This is due to the } \\
\text { insufficient land used for citrus cultivation. Besides, several factors influence } \\
\text { the production and quality of citrus, namely genetics, cultivation, and post- } \\
\text { harvest handling, as well as other environmental factors, namely land. } \\
\text { Environmental factors that affect the production and quality of citrus are soil } \\
\text { and climate. Soil factors include altitude, topography, drainage, soil type, soil } \\
\text { physical properties, and soil chemical properties, while climatic factors include } \\
\text { rainfall and temperature. On a large scale, these environmental factors are } \\
\text { difficult to modify, so to avoid the risk of damage and death, citrus plants are } \\
\text { recommended to be planted on suitable land. The purpose of land suitability } \\
\text { research is also intended to increase the production and quality of oranges. }\end{array}$ \\
\hline Keywords
\end{tabular}

environmental factors;

land suitability;

production;

quality;

soil type;

International Journal of Life Sciences (C) 2020.

This is an open access article under the CC BY-NC-ND license

(https://creativecommons.org/licenses/by-nc-nd/4.0/).

\section{Contents}

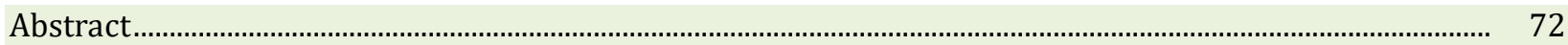

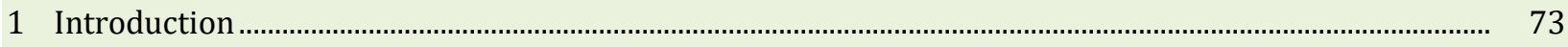

2 Materials and Methods................................................................................................................................. 74

3 Results and Discussions ............................................................................................................................... 74

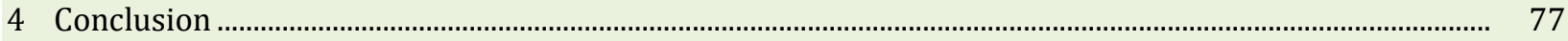

Acknowledgments......................................................................................................................................... 77

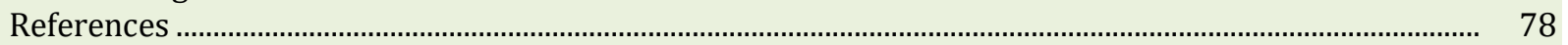

${ }^{a}$ Faculty of Agriculture, Warmadewa University, Denpasar, Indonesia

${ }^{b}$ Faculty of Agriculture, Warmadewa University, Denpasar, Indonesia

${ }^{c}$ Faculty of Agriculture, Warmadewa University, Denpasar, Indonesia 


\section{Introduction}

Oranges are the third most important fruit commodity in Indonesia after bananas and mangoes, both in terms of production quantity and consumption needs as well as from their trade value. Siamese orange (Citrus nobilis var. Microcarpa Hassk) is one of the most cultivated citrus types and dominates $60 \%$ of the national and regional citrus market (Anwar et al., 2015). In Bali, the production centers for Siamese oranges are in Kintamani District, Bangli Regency, Petang District, Badung Regency, and Payangan District and Tegalalang District, Gianyar Regency.

Fruit plants have different flowering periods. Plants will enter the flowering phase after passing through the vegetative phase. The occurrence of these phases is very much influenced by the surrounding environment, such as the duration of exposure, temperature, and humidity. According to Seghieri et al. (2009), the flowering process in plants is associated with various biotic and abiotic environmental conditions. Flowering studies on fruit trees are very important to study because they are needed in garden management so that fertilization, pruning, irrigation, and plant manipulation schedules can be carried out appropriately (Liferdi \& Darusman, 2000).

Plant growth and development can be seen from the pattern of crown growth, root growth, flowering, and fruiting. Plant environmental factors will affect the physiological activity of plants which have a direct impact on the growth and development phases of plants. Climatic elements that affect physiological processes are abiotic stresses such as air temperature, humidity, rainfall, drought, day length, and irradiation intensity (Thamrin et al., 2009). Physiological processes that occur in the Siamese citrus plant will then affect other accredited parts of the plant to reach a certain growth limit, for example, vegetative growth stops when the plant enters the flowering phase (Liferdi \& Darusman, 2000; Tonga et al., 2017). Plant growth and development can be seen from the pattern of crown growth, root growth, flowering, and fertilization.

Climatic factors that affect the phenomenon of flowering plants to form fruit crops are influenced by, among others: rainfall, temperature, radiation, and drought stress (Dutta \& Devi, 2015; Kebede \& Isotalo, 2016). The climatic factor that is often used in the study of flowering in fruit crops is rainfall. Such as the formation of flowers on the rambutan plant is closely related to the length of the dry period (Handayani et al., 2016). Climate change causes changes in environmental conditions which result in less than optimal growth and development of plants. In less than optimal conditions, plant growth will be disrupted which in turn reduces production and yield quality. Every plant needs different climatic conditions to be able to produce optimally so that climate change will have different impacts on each type of plant. There are so many horticultural crops that it is difficult to conclude the impact of climate change on the growth and production of this commodity in general. Therefore, intensive and comprehensive research is needed (Hutabarat et al., 2016).

The impact of climate change on horticultural commodity production also depends on geographic conditions and the intensity of climate change itself (Webb et al., 2014). To determine the impact of climate change on horticultural commodities, information on the physiological response of growth, development and quality, production, and productivity of plants is needed. Plants that experience water stress will decrease their vegetative growth and can store carbon (C) so that with a larger amount of $\mathrm{C}$, this condition will spur generative growth. Provision of water will increase the C / N ratio in the plant body. A High C / N ratio results in the accumulation of carbohydrates, which in turn stimulates the formation of flowers and fruit. The high percentage of fallen flowers is related to unfavorable climatic conditions, namely low rainfall intensity and the number of rainy days so that plants lack water which disrupts plant physiological processes (Moretti et al., 2010). Rainfall associated with water availability for plants has an important role in increasing the nutritional content and quality of plants. Lack of water can cause plants to experience stress and even death. The increase in water availability in tomatoes causes the color of the fruit skin to become more attractive, the weight of the fruit and the total acid increases, but decreases the value of total dissolved solids (TPT) (Barbagallo et al., 2012).

Climatic conditions play an important role because they affect production potential. The rain has a major impact on the production of Siamese oranges. The growth of Siam orange requires rainfall $>1250 \mathrm{~mm} /$ year

Sulistiawati, N. P. A., Suaria, I. N., \& Astiari, N. K. A. (2020). The relationship of agro-climatic characteristics in flowering phenology of siam citr plants (Citrus nobillias Var microcarpa L). International Journal of

Life Sciences, 4(3), 72-79. https://doi.org/10.29332/ijls.v4n3.580 
with evenly distributed rainfall throughout the year (Siregar, 2006). The level of rainfall can be carried out as an evaluation of products for the coming years. According to Sunarko (2007), the distribution of production every month in a year is strongly influenced by rainfall in previous years. An understanding of the influence of weather elements and plant age on growth, development, flowering, and fruiting is needed as a basis for predicting and evaluating the productivity of Siamese citrus plants.

\section{Research objectives}

The aim of this study:

1) The number of distributions of micro-climate conditions in three locations, Kintamani District, Bangli Regency, Petang District, Badung Regency, and Payangan District, Gianyar Regency.

2) The number of productivity distribution of Siamese oranges in three locations, Kintamani District, Bangli Regency, Petang District, Badung Regency, and Payangan District, Gianyar Regency.

3) To analyze differences in microclimate conditions and productivity of Siamese oranges based on rainfall and duration of rainy days. This research was conducted in three locations in Kintamani District, Bangli Regency, Petang District, Badung Regency, and Payangan District, Gianyar Regency.

\section{Materials and Methods}

\section{Place and Time}

The research will be carried out in gardens owned by citrus farmers in three locations, Kintamani District, Bangli Regency, Petang District, Badung Regency, and Payangan District, Gianyar Regency from March 2020 to September 2020.

\section{Materials and Tools Materials}

The materials and tools used were 36-year-old Siamese oranges. The tools used in this research were cloth meter, SPAD meter, hand refractometer, and stationery.

\section{Research Procedures}

The research was carried out by collecting plant growth data and observing factors related to the flowering of the Siamese citrus plant. Important information needed besides morphological changes is the time of flowering. Labeling is done when the plants begin to flower. Labeling is intended to determine the panicles from which to sample the fruit.

\section{Observed variables}

The variables observed consisted of: 1) When the flowers bloom. observations are made every day recorded when the flowers in the panicles have bloomed, 2) Percentage of fruit-set, observations are made by counting the number of flowers per panicle and the number of prospective fruit, then the number of prospective fruit is compared with the number of flowers. Observations were made every four days.

\section{Results and Discussions}

The results of identification of changes in the morphology of the phases of flowering macroscopically from before induction to blooming and descriptions that show important events in the developmental phases of Siam orange flowers. The developmental phases of flowering are: a) Before the induction of the first stage of the flowering process, which is the stage when the vegetative meristem begins to transform into the reproductive meristem, occurs in the cell, it can be detected chemically from the increased synthesis of nucleic 
acids and proteins required for division and cell development, b) Flower induction, the stage when the morphological changes to reproductive bud form can be detected macroscopically for the first time, c) the development of flower buds towards anthesis is usually called differentiation, namely the parts of the flower in this phase the processes of megasporogenesis and microsporogenesis occur for improvement and maturation of male and female reproductive organs, d) blooming stage when there is blooming of flowers or anthesis (Essono et al., 2007; Guédon \& Legave, 2008). Observations of the flowering and fruiting process in Siamese oranges show that the Siamese citrus flowers bloom in September-November 2019, June-August 2020 fruit in the Gadu period. November-December 2019 flowering and fruit harvest in June-August 2020 Sela.

The initiation of flowering occurs during the dry season for one month. Drought-stricken conditions with only six rainy days the following month stimulated the plants to flower. Induction of flowering due to drought stress also appears to have occurred in the second period, with rainfall in the month before flowering was only $17.7 \mathrm{~mm}$ per month. The number of dry/sunny days needed to induce flowering in Siamese oranges is described as 4 rainy days and no rain remaining. It can be explained that four days of dry real Siamese orange can stimulate flowering in Siamese oranges (Table 1).

The development of plants, especially flowering, is very dependent on several environmental and internal factors of mango (Santosa et al., 2014). Environmental temperature and water drought stress are environmental factors that influence the induction of flowering. Furthermore, the results of research (Handayani et al., 2016) on mango plants showed that temperatures below $22.15^{\circ} \mathrm{C}$ and a little rain after experiencing drought caused the induction of flowering. In subtropical areas, the temperature is an environmental factor that affects the mango flowering process. A temperature of $18^{\circ} \mathrm{C}$ during the day and $10^{\circ}$ $\mathrm{C}$ at night triggers the development of flowers in the generative shoots of mango plants (Chmielewskiet al., 2004). In line with the opinion (Ramires et al., 2014), water stress or drought stress can inhibit the induction of flowering shortly after the initiation of shoots on mango plants.

The average age of harvested Siamese oranges in Catur Village observed was the day after flower initiation. The number of flowers continued to increase each observation period, a decrease in the number of blooming flowers occurred after the flowers bloomed, followed by the loss of stamens, namely in the observation period of three days. After the fruit is formed. In line with (Pulatov et al., 2015), the flowering process contains some important steps, all of which must be successfully carried out by plants to obtain physiological ripe fruit. After the fruit is formed, the length of the flower/fruit increases again. The harvest age of Siamese oranges is influenced by the temperature. High temperatures can speed up the harvest of Siamese oranges. Temperature also affects the formation of yellow in fruit (Khandaker et al., 2011). The harvest age for Siamese oranges is almost the same at every harvest period. This is thought to be because the average maximum and minimum temperatures in Catur Village are almost the same from month to month (Table 1). The highest percentage of flower loss in Siamese oranges in the first period, around 26 flowers planted.

The flowering of Siamese oranges as a reproductive event is the main key to fruit production. The stage after the flowers bloom, the next process is the formation of young fruit (Pau et al., 2011; Pieri et al., 2010; Primack et al., 2009). Approximately 36 weeks or 252 days after the flowers bloom, the Siamese citrus plant will form ready-to-harvest fruit, both in the gadu and intermittent observation period. In the observation area, the average temperature is $18.29^{\circ} \mathrm{C}$ in the morning $19.98^{\circ} \mathrm{C}$ in the afternoon $20.07^{\circ} \mathrm{C}$ so that the average temperature in the on-season period from November to December 2017 is $19.47^{\circ} \mathrm{C}$ with an average humidity of $87,65 \%$ (Table 3.3), the average monthly rain was $185.48 \mathrm{~mm} /$ month with 17.4 rainy days (Table 3.1) there was flowering and in July-August 2018 the on-season harvest of Siamese citrus fruit entered the offseason period, namely October-November 2016 and the off-season harvest in November-December 2016 produced off-season fruit with an average amount of rainfall of $177.54 \mathrm{~mm} / \mathrm{month}$ with 5 rainy days (Table 3.1 ), followed by a condition of $30.18^{\circ}$ daily average temperature $\mathrm{C}$ in the morning, $32.75^{\circ} \mathrm{C}$ in the afternoon, $29.89^{\circ} \mathrm{C}$ at night the average daily temperature is $30.94^{\circ} \mathrm{C}$ (Table 3.3) with a humidity of $79.67 \%$ (Table 3.3) the occurrence of more flowering induction in the on-season period when compared to the off-season period the temperature is higher. It has been reported that citrus plants are induced to flower.

Sulistiawati, N. P. A., Suaria, I. N., \& Astiari, N. K. A. (2020). The relationship of agro-climatic characteristics in flowering phenology of siam citr plants (Citrus nobillias Var microcarpa L). International Journal of Life Sciences, 4(3), 72-79. https://doi.org/10.29332/ijls.v4n3.580 
Table 1

In the first period, about 26 flowers were planted

The average air temperature at the Catur-Bangli Village research location in 2019-2020

\begin{tabular}{|c|c|c|c|c|c|}
\hline \multirow{2}{*}{ Month } & \multirow{2}{*}{ Year } & \multicolumn{4}{|c|}{ Average temperature $\left({ }^{\circ} \mathrm{C}\right)$} \\
\hline & & Susut & Kintamani & Gianyar & Average \\
\hline September & 2018 & 30,18 & 32,75 & 29,89 & 30,04 \\
\hline October & 2018 & 30,55 & 31,85 & 29,87 & 30,25 \\
\hline November & 2018 & 29,05 & 30,67 & 28,25 & 30,92 \\
\hline December & 2018 & 28,15 & 29,15 & 28,52 & 28,16 \\
\hline January & 2019 & 28,27 & 29,16 & 28,18 & 28,65 \\
\hline February & 2019 & 27,89 & 30,67 & 28,32 & 28,96 \\
\hline March & 2019 & 29,18 & 31,17 & 29,34 & 29,90 \\
\hline April & 2019 & 29,76 & 30,87 & 31,14 & 30,46 \\
\hline May & 2019 & 29,78 & 31,17 & 30,15 & 30,37 \\
\hline June & 2019 & 29,36 & 30,53 & 30,16 & 30,01 \\
\hline July & 2019 & 28,64 & 31,17 & 30,12 & 30,03 \\
\hline August & 2019 & 30,13 & 31,14 & 30,43 & 30,58 \\
\hline September & 2019 & 28,18 & 27,75 & 27,58 & 28,17 \\
\hline October & 2019 & 18,24 & 20,45 & 20,17 & 19,87 \\
\hline November & 2019 & 20,15 & 20,25 & 19,18 & 19,47 \\
\hline December & 2019 & 20,09 & 20,19 & 18,12 & 19,46 \\
\hline January & 2020 & 20,10 & 20,89 & 19,23 & 20,07 \\
\hline February & 2020 & 20,14 & 20,98 & 20,24 & 20,45 \\
\hline March & 2020 & 27,32 & 29,14 & 28,15 & 28,20 \\
\hline April & 2020 & 27,18 & 29,28 & 28,16 & 28,21 \\
\hline May & 2020 & 28,19 & 30,15 & 29,09 & 29,14 \\
\hline June & 2020 & 29,19 & 30,59 & 29,65 & 29,81 \\
\hline July & 2020 & 28,89 & 30,04 & 29,91 & 29,61 \\
\hline August & 2020 & 29,18 & 31,02 & 29,75 & 29,98 \\
\hline September & 2020 & 29,89 & 30,19 & 28,19 & 29,42 \\
\hline
\end{tabular}

Description: Source at the research location in Chess Village, Bangli Regency, 2019-2020 The lowest interest loss is in the period

Badung Regency, which is 6 flowers per tree. The high percentage of fallen flowers at a location with a lower altitude is related to less supportive climatic conditions at that time, namely low intensity of rainfall and number of rainy days so that plants lack water which disrupts plant physiological processes (Moretti et al., 2010). In the growth of the Siamese citrus plant, there are two important stages, namely the initiation stage where this stage is the initial stage of shoot growth. Furthermore, there will be an induction stage where at this stage it will determine the shape of the shoot growth into a vegetative or generative shoot.

Table 2

Average rainfall (mm) in the three research locations in Bangli, Gianyar, and Badung Regencies

\begin{tabular}{rlllll}
\hline No & Month & Year & Badung & Gianyar & Bangli \\
\hline 1 & September & 2018 & 17.7 & 14 & 12 \\
2 & October & 2018 & 38 & 31 & 20 \\
3 & November & 2018 & 141 & 82 & 56 \\
4 & December & 2018 & 377 & 233 & 156 \\
5 & January & 2019 & 387 & 128 & 109 \\
6 & February & 2019 & 225 & 203 & 145 \\
7 & March & 2019 & 278 & 219 & 114 \\
8 & April & 2019 & 238.5 & 217 & 134 \\
\hline
\end{tabular}




\begin{tabular}{clllll}
\hline 9 & May & 2019 & 239 & 215 & 132 \\
10 & June & 2019 & 59 & 42 & 30 \\
11 & July & 2019 & 77 & 54 & 45 \\
12 & August & 2019 & 42 & 23 & 21 \\
13 & September & 2019 & 21 & 14 & 10 \\
14 & October & 2019 & 6 & 2 & 4 \\
15 & November & 2019 & 13 & 12 & 8 \\
16 & December & 2019 & 211.50 & 117.4 & 97 \\
17 & January & 2020 & 479 & 325 & 189 \\
18 & February & 2020 & 486 & 327 & 203 \\
19 & March & 2020 & 376 & 322 & 121 \\
20 & April & 2020 & 148 & 117 & 12 \\
21 & May & 2020 & 16,5 & 12,5 & 3 \\
22 & June & 2020 & 6,76 & 4 & 2 \\
23 & July & 2020 & 10 & 4 & 3 \\
24 & August & 2020 & 6.8 & 3 & 4 \\
25 & September & 2020 & 6,7 & 4 & Distict Badug
\end{tabular}

Description: Source BMKG. Chess Village, Bangli Regency, Gianyar District, and Petang District Badung Regency in 2019-2020

The highest mean value of total dissolved solids (TPT) was found at the first harvest of the on-season period, namely $5.98^{\circ}$ bricks, and the lowest at the interim harvest, namely $4.59^{\circ}$ bricks (Table 5). The first harvest in the gadu period takes place at the end of the dry season, so the plants may experience stress.

\section{Conclusion}

A long dry period can stimulate flowering in the developmental physiology of Siamese citrus. The highest flower loss occurs at harvest when the amount of rainfall is high with low humidity, with high temperatures occurring during the gadu period, and the lowest at harvesting during the intermittent period.

Acknowledgments

We are grateful to two anonymous reviewers for their valuable comments on the earlier version of this paper.

Sulistiawati, N. P. A., Suaria, I. N., \& Astiari, N. K. A. (2020). The relationship of agro-climatic characteristics in flowering phenology of siam citr plants (Citrus nobillias Var microcarpa L). International Journal of Life Sciences, 4(3), 72-79. https://doi.org/10.29332/ijls.v4n3.580 


\section{References}

Anwar, M. R., Li Liu, D., Farquharson, R., Macadam, I., Abadi, A., Finlayson, J., ... \& Ramilan, T. (2015). Climate change impacts on phenology and yields of five broadacre crops at four climatologically distinct locations in Australia. Agricultural Systems, 132, 133-144. https://doi.org/10.1016/j.agsy.2014.09.010

Barbagallo, R. N., Chisari, M., \& Caputa, G. (2012). Effects of calcium citrate and ascorbate as inhibitors of browning and softening in minimally processed 'Birgah'eggplants. Postharvest Biology and Technology, 73, 107-114. https://doi.org/10.1016/j.postharvbio.2012.06.006

Chmielewski, F. M., Müller, A., \& Bruns, E. (2004). Climate changes and trends in phenology of fruit trees and field crops in Germany, 1961-2000. Agricultural and Forest Meteorology, 121(1-2), 69-78. https://doi.org/10.1016/S0168-1923(03)00161-8

Dutta, G., \& Devi, A. (2015). Phenology and population structure of six tree species in tropical forest of Assam, northeast India. Tropical Ecology, 56(3), 393-399.

Essono, G. G., Ayodele, M., Akoa, A., Foko, J., Olembo, S., \& Gockowski, J. (2007). Aspergillus species of cassava chips in storage in rural areas of southern Cameroon: their relationship with storage duration, moisture content, and processing methods.

Guédon, Y., \& Legave, J. M. (2008). Analyzing the time-course variation of apple and pear tree dates of flowering stages in the global warming context. Ecological Modelling, 219(1-2), 189-199. https://doi.org/10.1016/j.ecolmodel.2008.08.010

Handayani, T., Basunanda, P., Murti, R. H., \& Sofiari, E. (2016). Perubahan morfologi dan toleransi tanaman kentang terhadap suhu tinggi.

Hutabarat, B., Setiyanto, A., Kustiari, R., \& Sulser, T. B. (2016). Conjecturing production, imports and consumption of horticulture in Indonesia in 2050: A GAMS simulation through changes in yields induced by climate change. Jurnal Agro Ekonomi, 30(1), 1-23.

Kebede, M., \& Isotalo, J. (2016). Tropical Ecology 57: 299-311.

Liferdi, R. P., \& Darusman, L. K. (2000). Studi Fenofisiologi Rambutan (Nephelium lappaceum L). Comm. $A g, 5(2), 44-52$.

Moneruzzaman, K. M., Al-Saif, A. M., Alebidi, A. I., Hossain, A. B. M. S., Normaniza, O., \& Boyce, A. N. (2011). An evaluation of the nutritional quality evaluation of three cultivars of Syzygium samarangense under Malaysian conditions. African Journal of Agricultural Research, 6(3), 545-552.

Moretti, C. L., Mattos, L. M., Calbo, A. G., \& Sargent, S. A. (2010). Climate changes and potential impacts on postharvest quality of fruit and vegetable crops: a review. Food Research International, 43(7), 1824-1832. https://doi.org/10.1016/j.foodres.2009.10.013

Morinaga, K. (2007). Impact of Climate Change on Horticulture Industry and Technological Countermeasuresin Japan 8.http://www.fftc.agnet.org/files/lib_articles/20120104150721/ eb629.pdf [15 Oktober 2017].

Pau, S., Wolkovich, E. M., Cook, B. I., Davies, T. J., Kraft, N. J., Bolmgren, K., ... \& Cleland, E. E. (2011). Predicting phenology by integrating ecology, evolution and climate science. Global Change Biology, 17(12), 36333643.

Pieri, P., Lebon, E., \& Brisson, N. (2010). Climate change impact on French vineyards as predicted by models. In XXVIII International Horticultural Congress on Science and Horticulture for People (IHC2010): International Symposium on the 931 (pp. 29-37).

Primack, R. B., Higuchi, H., \& Miller-Rushing, A. J. (2009). The impact of climate change on cherry trees and other species in Japan. Biological $1943-1949$. https://doi.org/10.1016/j.biocon.2009.03.016

Pulatov, B., Linderson, M. L., Hall, K., \& Jönsson, A. M. (2015). Modeling climate change impact on potato crop phenology, and risk of frost damage and heat stress in northern Europe. Agricultural and Forest Meteorology, 214, 281-292. https://doi.org/10.1016/j.agrformet.2015.08.266

Ramires, E. K. N. M., Menezes, R. C. E. D., Oliveira, J. S., Oliveira, M. A. A., Temoteo, T. L., Longo-Silva, G., ... \& Asakura, L. (2014). Nutritional status of children and adolescents from a town in the semiarid Northeastern Brazil. Revista paulista de pediatria, 32(3), 200-207.

Santosa, F., Moysidis, T., Moerchel, C., Kröger, K., \& Bufe, A. (2014). Pulmonary embolism in young people. Hämostaseologie, 34(01), 88-92. 
Seghieri, J., Vescovo, A., Padel, K., Soubie, R., Arjounin, M., Boulain, N., ... \& Peugeot, C. (2009). Relationships between climate, soil moisture and phenology of the woody cover in two sites located along the West African latitudinal gradient.Journal of Hydrology, 375(1-2), $78-89$. https://doi.org/10.1016/j.jhydrol.2009.01.023

Siregar, R. S. (2006). Akne Vulgaris Atlas Berwarna Saripati Penyakit. Jakarta. EGC.

Sunarko, I. (2007). Petunjuk Praktis Budi Daya \& Pengolahan Kelapa Sawit. AgroMedia.

Thamrin, M., Susanto, S., \& Santosa, E. (2009). Efektivitas Strangulasi terhadap pembungaan tanaman jeruk pamelo 'Cikoneng'(Citrus grandis (L.) Osbeck) pada tingkat beban buah sebelumnya yang berbeda. Jurnal Agronomi Indonesia (Indonesian Journal of Agronomy), 37(1).

Tonga, Y., Kaca, I. N., Suariani, L., Sutapa, I. G., Yudiastari, N. M., \& Suwitari, N. K. E. (2017). The production and quality of mott grass (pennisetum purpureum CV. Mott) that intercropped with legume in the first pruning. International research journal of engineering, IT \& scientific research, 3(4), 88-101.

Webb, W. R., Muller, N. L., \& Naidich, D. P. (2014). High-resolution CT of the lung. Lippincott Williams \& Wilkins.

\section{Biography of Authors}

\begin{tabular}{|l|l||}
\hline & $\begin{array}{l}\text { Dr. Ir. Ni Putu Anom Sulistiawati, M.Si. is a lecturer in the Faculty of Agriculture, } \\
\text { Warmadewa University, Denpasar, Indonesia. She lives at Jln. Kori Agung Blok C } \\
\text { 29 Sading, Badung, Bali. } \\
\text { Email: putuanom2020@gmail.com }\end{array}$ \\
\hline & $\begin{array}{l}\text { Ir. I Nengah Suaria, M.Si. is a lecturer in the Faculty of Agriculture, Warmadewa } \\
\text { Denpasar, Indonesia. He lives at Jl. PB. Sudirman I RT. 07 No. 59, Denpasar, Bali. } \\
\text { Email: n.suria@gmail.com }\end{array}$ \\
\hline & $\begin{array}{l}\text { Ir. Ni Komang Alit Astiari, M.Si. is a lecturer in the Faculty of Agriculture, } \\
\text { Warmadewa University, Denpasar, Indonesia. She lives at Perumahan Padang Asri, } \\
\text { Blok IX/14, Padangsambian Kelod, Denpasar Barat, Denpasar, Bali } \\
\text { Email: alit.astiari@gmail.com }\end{array}$ \\
\hline
\end{tabular}

Sulistiawati, N. P. A., Suaria, I. N., \& Astiari, N. K. A. (2020). The relationship of agro-climatic characteristics in flowering phenology of siam citr plants (Citrus nobillias Var microcarpa L). International Journal of Life Sciences, 4(3), 72-79. https://doi.org/10.29332/ijls.v4n3.580 